\title{
Haber Etiği ve Bir Siyasi Haber İncelemesi
}

BUĞRA KARDAN*

bugra.kardan@gmail.com

Özet: Medyada haber etiği ve habercilik ahlakı tartışmaları, medya tarihi kadar eski bir olgudur. İletişim teknolojisinin sağladığı imkânlarla faaliyet çeşitliliği, etki gücü ve etki alanı hızla artan basın-yayın sektörü, siyasi ve/veya mali hedefler gözeten birer araç olarak artık daha sık kullanılmakta ve ortaya çıkan etik (ve adli) sorunlar, medyada haber etiğg tartışmalarının güncel kalması sonucunu doğurmaktadır. Bu çalı̧̧mada medyada haber etiği konusu, siyasi bir haber (bir siyasi parti genel başkanına dönük şiddet eylemi haberi) çerçevesinde ele alınmış; olayın farkh siyasi duruşlardaki bazı medya organları (gazeteler) tarafından haberleştirilme biçimi, belirli kıstaslar altında toplanan veriler eşliğinde, haber etiği perspektifivle ve karşılaştırmalı olarak incelenmiştir. Yapılan inceleme sonuçlarına göre, özellikle bazı gazetelerde söz konusu haberin sunuş biçimi üzerinde medya organlarının siyasi pozisyonlarının etkili olabildiği gözlemlenmiştir.

Anahtar kelimeler: Medya, Haber etiği, Siyasi haber, Basın ahlakı, Tarafsızlı.

\section{Giriş}

20. yüzyılın ikinci yarısından itibaren, hem siyasal ortamın hem de teknolojik gelişmelerin sağladığı ivmeyle iletişim imkânları daha da artmış, haberleşme imkânları açısından çok daha açık bir ortama girilmiştir. Önceki dönemlere kıyasla iletişim vasıtalarının etki ve öneminin hızla arttığı bu "küreselleşme" döneminde, medyanın kuvveti ve kudreti de doğal olarak artmıştır. Medya hem ulusal hem de uluslararası düzeyde toplumların fikirlerine yön verebilecek bir güce ulaşmıştır. Hızla artan ağırlığı ile siyasi alanı da şekillendirebilen basın-yayın organlarının bu gücünün kötüye kullanımına dönük etik tartışmaların tarihi de doğal olarak oldukça eskidir. Bu tartışmaların ekseninde başta medya sektöründeki tekelleşme ve kartelleşme eğilimleri olmak üzere medya sermayedarlarının ayrı sektörlerde faaliyet yürütmeleri nedeniyle siyasi iktidarlarla aralarında mali bakımdan doğal bir menfaat ya da çatışma zemininin ortaya çıkması yer almaktadır.

Medyanın en önemli görevlerinden biri haber vermek, topluma olayları bildirmektir. Siyasi ve sosyal alanı hem sunan hem de yeniden inşa edebilen haberin etik olup olmadığı sorusu önem kazanmaktır. Bu çerçevede, etik değer ve ilkeler temel oluşturmaktadır. Medya ve haber etiği bağlamında en çok başvurulan kavramlar doğruluk

\footnotetext{
* Marmara Üniversitesi Sosyal Bilimler Enstitüsü, Radyo-Televizyon ve Sinema Anabilim Dalı Yüksek Lisans Öğrencisi
} 
ve nesnelliktir. Çünkü bu kavramlar ile medya ve haber etiği ilkelerinin büyük bölümü inşa edilmektedir. Basın-yayın organları için güvenilirliğin ve saygınlığın şartları arasında doğruluk ve nesnellik önrmli yer tutmaktadır. Bu çalışma farklı sermaye gruplarını ve ideolojik bakışları temsil eden beş gazetenin CHP Genel Başkanı Kemal Kılıçdaroğlu'na Meclis'te yapılan yumruklu saldırıyı haberleştirirken ne ölçüde etik değerlere uygun davrandıklarını belirlemeyi amaçlamaktadır. Çalışmada, içerik analizi yöntemine başvurulmuş; okurların önemli bölümüne hitap eden Hürriyet, Sözcü, Zaman, Sabah, Yeni Akit' in haber, manşet, sayfa, fotoğraf ve karikatür sayısına dair veriler toplanmış; gazeteler karşılaştırmalı olarak ele alınmıştır. Ayrıca haberlerde geçen konular ve kullanılan anahtar sözcükler çıkarılmış; yorumlara, suçlamalara ve varsayımlara dayanan cümleler ortaya konularak gazetelerin olayı ne yönde alg1layıp okura sunduğu ve etik kurallara ne oranda riayet ettikleri saptanmaya çalışılmiştır.

\section{Etik Kavramı ve Medya Etiği ile İlgili Tartışma Alanları}

Etik, ahlaki kuralları ve değerleri ele alan felsefe dalıdır. Etik, ideal ahlakı aramakta ve bu anlamda topluma önerilerde bulunmaktadır. Öneriler, ortak akla ve deneyimlere dayanmaktadır. Bireylere ne yapmaları veya yapmamaları gerektiğini anlatan etik, davranışlara ve davranışların temellerine odaklanmaktadır (Erondu, Sharland ve Okpara, 2004, s. 349-357).

Etik ve ahlak kavramları günlük kullanımda kimi zaman birbiriyle karıştırılabilmektedir. Ahlak, belli bir dönemde, belli toplumlar tarafından onaylanan davranış kurallarının ve ilkelerinin tamamıdır (Atabek, 2006, s. 1). Bu kurallar doğal ya da normal olana veya olmayana işaret etmektedir. Bu kurallar kaçınılacak, kaçınılmayacak eylemleri ilan etmektedir (Tepe, 1992, s. 5). Etik ise ahlak kurallarının toplumun ruhuna uygun olup olmadığını araştırır, bu anlamda en iyiyi elde etme yöntemlerini vurgulamaktadır. "Ahlak"ın alanı "etik"e göre daha kapsamlıdır. Ahlak, toplumun tamamına hitap eden kurallar koyar. Ancak etik toplumun belli bir bölümü, belli bir meslek dalı için kurallar koyar. Bu meslek dallarından biri de, toplumda önemi giderek artan medyadır. Medya etiği ile ilgili tartışmalarda basın özgürlügüü önemli bir yer tutar. Basın özgürlügü ifade özgürlügünün temelidir (Belsey ve Chadwick, 2011, s. 31). Muhtelif karar ve bildirilerde ifade özgürlüğü kapsamında ele alınan basın özgürlüğü, haber verilerinin müdahalelerden ari olarak elde edilmesi ve yayınlanmasıdır. Esasında basın özgürlügü kavramı ile siyasilerin, sermayenin güdümünden bağımsız medyadan söz edilmektedir (Banar vd. 2013, s. 12-13). Siyaset ve sermaye ile bağları medya şirketlerini müdahalelere açık hale getirmektedir. Bu müdahaleler, ahlaki ilkelerin belli bölümünden ya da tamamından sapmalara neden olabilmektedir. Onun için özerk ve özgür medya, modern dönemin ruhuna uygun görülmekte ve önerilmektedir.

Medya etiği oldukça köklü bir geçmişe sahiptir. 20. yüzyılın önemli konularından olsa da medya etiğinin önde gelen kavramlarından basın özgürlüğüyle ilgili tartışmalar 17. ve 18. yüzyıllara dayanmaktadır. Bu tartışmaların ardından basın özgürlüğünü arttırıcı önlemler alınmıştır. 19. yüzyılın sonu ve 20. yüzyılın başlarından 
itibaren de Anglo-Amerikan haberciliğinde nesnellik, tarafsızlık, yansızlık gibi değerlerin önemi artmıştır. Bununla uyumlu olarak doğan gazetecilikte sorumluluk ilkesi, toplumsal sorumluluk kuramı haline gelmiştir. Kuram, Hutchins Komisyonu Raporu'yla temellenmiştir. Raporda medyanın topluma karşı ödevlerini tam olarak ifa edebilmesi, özgürlüklerin yanında sorumluluklarını anlamasına ve devlet müdahalesine dayanmamasına bağlanmıştır. Komisyonun önerileri, liberal anlayışa dayanarak öz denetimi esas almış; medya etiğiyle ilgili tartışmaların ana çerçevesini belirlemiştir (Taş, 2010, s. 17-18).

Hutchins Komisyonu Raporu'nun ardından ortaya konulan 1977-1980 tarihli Mc Bride Komisyonu Raporu da Birleşmiş Milletler Eğitim, Bilim ve Kültür Örgütü UNESCO'nun projelerine temel olmuştur. UNESCO projelerinde toplumsal sorumluluk, etik ve kendi kendini denetim değerli kavramlar olarak görülmüştür. 1990'dan itibaren ise şeffaflığa ve denetime açıklığa medya etiği bağlamında önemle değinilmiştir. Bu dönemde medya şirketleri ombudsman, okur temsilcisi istihdam etmeye, cemiyet ve dernekler denetime yönelmiştir (Taş, 2010, s. 19-20).

Türkiye'de de medya etik ilkeleri ile ilgili girişimler 1960 sonrası artmıştır. 27 Mayıs sonrası 24 Temmuz 1960'ta Türkiye Gazeteciler Cemiyeti önderliğinde Basın Ahlak Yasası belirlenmiştir. 9 maddeli metnin ilkelerini denetlemek için Basın Şeref Divanı devreye alınmıştır. Basın Ahlak Yasası'nın etik sorunları tam olarak önleyememesi üzerine 14 Şubat 1972'de Gazeteciler Cemiyeti Genel Kurulu'nda kabul edilen Gazetecilerin Basın Ahlak Kuralları adlı ilkeler konulmuştur (Özgen, 2002, s. 188).

Basın Konseyi'nin 6 Şubat 1988 tarihinde ilanı ile kabul edilen 16 maddeli Basın Meslek İlkeleri medya etiği ile ilgili diğer bir önemli metindir. Bu anlamda en kapsamlı görülen etik ilkeler de Türkiye Gazeteciler Cemiyeti tarafından 18 Kasım 1998 tarihinde ilan edilen Türkiye Gazeteciler Hak ve Sorumluluklar Bildirgesi'dir. Halen geçerli olan bu metinden medya sektörü ve medya şirketleri, kendi kendini denetimde yararlanmaktadir.

\section{Medya-Sermaye Bağı ve Etik}

Soğuk savaşın ardından açık bir ortama girilmiş; bu ortamda uydudan yararlanarak uluslararası iletişime yön veren şirketler doğmuştur. Disney, News Corparation, Viacom, Time Warner gibi gruplar içeriklerini dünyanın büyük bölümüne satmaya başlamıştır. Bu gruplar; satın almalarla büyümeyi veya ortak menfaatlerde buluşup anlaşmayı tercih etmiştir. Türkiye'de de aynı eğilim görülmüştür. Bu dönemde Türkiye'de holdingler, medya sektörüne girerek önemli aktörler haline gelmiş; bir yandan gazete, radyo ve TV kanallarını bünyelerinde toplamış; diğer yandan aralarında anlaşmalar yapmış; ayrı sesleri önleme yoluna gitmiştir. Bu dönemde basın özgürlüğü temel tartışma alanlarından olmuştur. Çünkü medya şirketlerinin ve habercilerin engeller veya müdahaleler ile karşı karşıya kalmaksızın yayıncılık yapmaları güçleşmiş, sonrasında ciddi etik sorunlar belirmiştir.

Mülkiyet yapısı basının faaliyetlerinde önemli bir etkendir, bu gücü medya patronları ve ortakları kendi menfaatleri için kullanmaktadır (Toruk, 2007, s. 72). Böyle bir 
ortamda doğal olarak içeriklere müdahale artmaktadır. Medya şirketlerinin mülkiyet yapısı haberlerin de kamuoyuna ne şekilde verildiğinde belirleyici olabilmektedir (Gürkan, 1997, s. 130).

Medyanın mülkiyet yapısı ile ilgili tartışmalar, tekelleşme ve kartelleşme kavramlarında yoğunlaşmaktadır. Tekelleşme; basın kurumlarının bir ya da birkaç elde toplanması anlamına gelmektedir. Medyada birkaç büyük kurumun ortak menfaatlerde buluşup yayın anlayışı ya da diğer ticari netice doğuracak hususlarda birlikte hareket etmesi ise kartelleşme olarak ifade edilmektedir. Tekelleşme ve kartelleşme, medyada rekabete darbe vurmakta, çok sesliliği önlemektedir. Bu iki kavram manipülasyona da neden olmaktadır. Burada iki alanda manipülasyon yapılmaktadır. İlki haberi yazan muhabiri, ikincisi haberi yayına verecek basın-yayın organını manipüle etmek ve yönlendirmektir (Bülbül, 2001, s. 74).

Medya-sermaye bağında reklam da önemli bir öğedir. Medya şirketleri için reklam çok önemli bir gelir alanıdır. Bu durum etik değerlerin ihmal edilmesine neden olabilmektedir. Reklam verenler, kendilerinde yayın içeriğine karışma, basın-yayın organlarını denetleme, yapım ve haberlere müdahale etme hakkını görebilmektedir. Bunun en yaygın örneği, reklam verenlerin kendileriyle ilgili yayınlanacak haberlerin ilk olarak kendilerine gönderilmesini talep etmeleridir. Bu şekilde arzu edilmeyen haberlerin önüne geçilmektedir (Banar vd. 2013, s.131). Yine şirketler, medya grupları tarafından yıpratılmaktan korktukları için reklam vermek zorunda kalabilmektedir. Yani zaman zaman reklam veren firma, medya şirketlerince baskı altına alınabilmektedir (Ünlüer, 2006, s. 4). Bu durum yayınlarda ve haberlerde özgür olamamaya; tarafgir davranmaya; reklam verenin olumsuz yanlarını görmezden gelmeye yani etik kurallara uymamaya itebilmektedir.

\section{Medya- Siyaset Bağı ve Etik}

Medya artan kuvveti ile siyasi hayatı da şekillendirmektedir. Bu şekillendirme esnasında devletten menfaat elde etme en önemli gaye olarak görülebilmekte, halkın sesi olma görevi geri plana atılabilmektedir (Şimşek, 2009, s. 126). Siyasiler ise medyayı bir güç olarak görmekte ve kontrol altına almaya çabalamaktadır. Siyasal iktidar ve devlet eliyle medyayı kontrol altına almayı en belirgin şekilde sansür kavramı ifade etmektedir. Sansür, bir yayının veya haber, görüntü ve fotoğrafların, devletin bir kurumu, bilhassa kolluk kuvvetleri tarafından engellenmesidir (Bülbül, 2001, s. 78). Sansür, basın özgürlüğ̈̈ bağlamında önemli bir sorun olarak görülmektedir. Medya sektörü, sorunun hem basin hem de toplum aleyhine işlediğini ifade etmektedir. Sektörün bu yaklaşımı da basın kurumlarının denetleme, topluma haber verme görevini görebilmesi için devlete bağlanmaması, sansür edilmemesi gerektiğini ortaya koymaktadır (Hatemi, 1976, s. 151). Günümüzde sansür, habere haber eklenmekle yapılmaktadır. Böylelikle haber saklanmış ya da budanmış olmakta, haber yığınları içinde hangi haberin eksik olduğu kolayca anlaşılamamaktadır (Ramonet, 2000, s. 56). Bu yöntemi siyasetçiler, ekonomik güç sahipleri, sivil toplum örgütlerinin yöneticileri, halkla ilişkiler uzmanları ve medya yöneticileri sık sık kullanarak gündem değiştirmekte, yeni gündemler yaratmakta, sonunda bireylerin kafalarını karıştır- 
dıklarından, amaçlarına uygun olarak toplumu tepkisizleştirmeye yöneltmektedirler (Girgin, 2005, s. 276). Akreditasyon uygulaması da sansür gibi medyayı kontrol altına almaya yöneliktir. Bu uygulama ile seçilmiş bazı medya kurumlarına ve görevlilerine kamu gücü etkisiyle ayrıcalıklı olarak haber sağlanmaktadır. Devlet teşviklerinin medyanın siyasal iktidarla ilişkilerine göre tahsis edilmesi de siyasilerin basın-yayın organlarını tahakkümlerine alma çabasının bir ürünüdür.

\section{Haber Etiği İle İlgili Tartışma Alanları}

Haber etiği ile ilgili kurallar, medyanın güvenilirliğini temin etmeye yöneliktir. Kurallar haber konularının itina ile araştırılmasına, yazılmasına imkân tanımaktadır. Habere konu olan hikâyeyi araştırma etabında etik konuma göre karar vermek gerekmektedir. Bu karar, haberin hangi metotlar ile araştırılacağı, hangi belgelere başvurulacağı ile ilgilidir. Haberin yapılıp yapılmayacağı da etik karar gerektirmektedir; reşit olmayanları konu alan kimi haberlerin yapılamayacağına hükmetmek gibi. Yine haberin hangi detayları içereceği hangi detayları içermeyeceği, ne şekilde verileceği de etik bir karar gerektirmektedir.

Bir topluma ve gruba üye olan habercinin dini, ırkı ve siyasi eğilimi bulunmaktadır. $\mathrm{Bu}$ durum haber tercihi ve yazımında yanlışlara neden olabilmektedir. Burada devreye doğruluk ve nesnellik girmektedir. Haber etiği bağlamında ilkeler, tartışmalar doğruluk ve nesnellik kavramı etrafında şekillenmektedir. Dünyanın ve Türkiye’nin önde gelen medya şirketleri buna dayanarak belli ahlaki ilkeler koymuştur. Örneğin pek çok ülkeye yayın yapan BBC’nin editoryal değerlerinden bir bölümü şöyledir (BBC’nin Editoryal Değerleri, 2014):

1. Gerçeklik ve Doğruluk

2. Tarafsızlık ve Fikir Çeşitliliği

3. Editoryal Dürüstlük ve Bağımsızlık

4. Kamu Yararının Gözetilmesi

5. Hakkaniyet

6. Mahremiyet

Hürriyet, Posta, Kanal D, Radyo D gibi önemli gazete ve TV kanallarını bünyesinde bulunduran Doğan Yayın Grubu'nun editoryal değerleri ise şöyledir (Doğan Yayın Grubu Ortak Değerleri, 2014):

1. Güven

2. Bağımsızlık

3. Doğruluk, Gerçeklik

4. Tarafsızlık, Çoğulculuk, Hakkaniyet

5. Toplum Değerlerine Uyum

6. Kişi Hakları ve Özel Hayatın Korunması

7. Şeffaflık ve Hesapverilebilirlik

8. Kurumsal Saygınlık 


\section{Haberde Doğruluk}

Medya haberleri ele aldığı konuları doğru ve eksiksiz bir biçimde yansıtmalıdır (Çaplı, 2002, s. 88). Bu husus medyanın güvenirliği açısından son derece önemlidir. Habercinin temel görevi olayı veya durumu açık ve anlaşılır olarak ortaya koymak, soru işaretlerine mahal vermemektir. Haberlerin gereken ayrıntıları ile doğru olarak topluma sunulmasında kamu yararı bulunmaktadır (Hatemi, 1976, s. 150). Bunun için haberlerde kullanılacak bulguların orijinalliğinden emin olunmalıdır. Tam doğrulanamayan haberler için editöre danışılmalıdır. Habere konu olan tarafların görüşlerine yer verilmeli, taraflara iddialara cevap verme hakkı sunulmalıdır (Demir, 2006, s. 61). Nihayetinde haberde etik sınırlar içinde kalmanın en önemli şartı hayati konuların, doğruluğundan kuşku duyulmayacak şekilde tam olarak anlatımıdır (Çaplı, 2002, s. 88).

Doğruluk kavramı, çarpıtmayı yani “dezenformasyon” kavramını ele almayı gerektirmektedir. Dezenformasyon, topluma bilinçli olarak yanlış haber vermektir. Bu yönteme genel olarak mali, siyasi ya da ideolojik saiklerle başvurulmaktadır.

Öte yandan haberciler, olayları olduğundan fazla büyütmemeli, metinde abartılı ifadelerden kaçınmalıdır. Yani herhangi bir olayda haber değeri olsun veya olmasın hikâye yaratmak için abartıya gitmek ahlaka ve doğruluk ilkesine aykırıdır (Almagor, 2002, s. 101-102). Esasında medyanın en önemli görevi kamuoyunun sesi olmaktır. Ancak bu görev çoğunlukla bir yana bırakılmaktadır. Yayınlar ve haberlerle toplum belli fikirlere ve görüşlere yönlendirilmektir.

\section{Haberde Nesnellik}

Medya haberlerinde nesnel bir tavır takınılmalıdır. Haberci, haber toplama ve yazım esnasında fikirlerini ve yorumlarını habere karıştırmamalıdır. Nesnel tavrın gereği olarak metinlerde yanlı ifadeler, suçlama ve varsayımlara dayanan yazılar bulunmamalıdır (Banar vd. 2013, s. 130). Bir topluma ve gruba üye olan muhabirin dini, uyruğu, siyasi eğilimi vardır; bu nedenle haber yazarken değer yargılarını kolayca bir yana bırakamaz. Yani haberci için olayları taraf olmadan ele almak güçtür. Tarafsız ve değer yargılarından ari bir veri sunmak pek mümkün değildir. Böyle bir durumda yani tam olarak tarafsız ve nesnel olamama durumunda gazeteci olaylara kendi görüşünü katarken karşıt görüşlere de yer vermelidir.

Haber yazımının yanında seçiminde de taraf olma sorunu görülmektedir. Çünkü haberci, önüne gelen yığınla olaydan birini seçip haber yapmaktadır. Burada da muhabirin kimliği ve siyasi eğilimleri rol oynamaktadır. Yani gazetecilik haber içeriklerinin seçicilik ve yorumlama gerektirdiği için tam anlamı ile tarafsızlık mümkün değildir (Banar vd. 2013, s. 130). Haber seçiminde editörden, diğer muhabirlerden fikir alarak; konu ve konuları tartışıp tartıştırarak sorunun önüne geçilebilir.

Öte yandan gazetecilikte nesnel tavrın gereği ve etik ilkelerin bir şartı olarak metinlerde dini ve milli değerleri, bireyleri ve grupları hedef alan aşağılayıcı sözcükler geçmemelidir. Demokratik ülkelerde yorum yapma özgürlügünün kesin sinırlama- 
ları yoktur. Ama bu konuda esas olan şeref kırıcı, kötüleyici, iftira edici yorumlardan kaçınarak, başkalarının hakkına saygı göstermektir. Bu husus hem hukukun hem ahlakın konusudur (Demir, 2006, s. 65). Haberde tarafsız olmaya, hakarete varan ifadeler kullanmamaya çok uluslu kurumlar, yapılar da önem vermiş; bu çerçevede ilkeler ve kurallar koymuştur. Örneğin UNESCO Basın Ahlak Projeleri dâhilinde dini, etnik veya ırkçı gerilimleri arttırıcı ve yaratıcı herhangi bir haberi yazmak veya mikrofondan okumaktan kaçınılması talep edilmiştir (Özgen, 1994, s. 89).

\section{Mahremiyetin İhlali}

Haber etiğinin en çok tartışılan yanlarından biri de mahremiyetin ihlalidir. Osman11-Türkçe sözlükte mahremiyet; mahrem olma hali, mahremlik şeklinde geçmektedir (Özön, 1971, s. 440). Toplumdan ve bireylerden saklanan, bilinmemesi temenni edilen konuları karşılayan mahremiyet, haberciler tarafından ihlal edilebilmektedir. İhlale dayanak yapılan önemli kavramlardan biri kamu yararıdır. Kamu yararı, devlet imkânlarının devleti idare edenler tarafından toplumun menfaatine kullanımını öngören değerlerdir. Bu kavram tartışmalara açık olup haberlerde karşılık bulmaktadır. Burada kamu görevlilerinin rüşvet, yolsuzluk gibi olaylara karışmaları halinde haberciler, mahremiyeti ihlal hakkını kendinde görür (Banar vd. 2013, s. 132). Bu durumlarda bile ihlal konu ile ilgili olmalıdır. Yine mahrem alana "toplumun merakını gidermek için” girildiği açıklaması yeterli görülmemektedir; burada yasal bir menfaatin somut şekilde beyan edilmesi gerekmektedir (Yüksel vd. 2013, s. 179).

\section{Gizlilik Kaydıyla Verilen Bilginin Yayımlanması}

"Off the record" olarak adlandırılan ve yayınlanmaması kaydıyla habercilere yapılan açılamaların metinde yer alması etik ilkelere aykırıdır. Burada haberci sözüne bağlı kalmalı, kaynağının güvenini sarsmamalıdır. "Off the record" açılklamaların doğruluğu tartışmalıdır. Bu açıklamaların bir olayın araştırılması için yapılma ihtimali vardır. "Off the record" ibareli beyanı yayınlamak kaynak tarafından yalanlanabilir, haberde ortaya atılan iddia veya iddiaları ispatlamak muhabir için sorunlu olabilir (Yüksel vd. 2013, s. 181).

\section{Mahreç ve Alıntı Sorunu}

Muhabir haberinde, yazar yazısında, foto muhabiri fotoğrafında yararlandığı mecraları mutlaka bildirmelidir. Alıntılanan haber veya yazının muhabir veya yazarı, kullanılan fotoğrafın fotoğrafçısı yahut foto muhabiri belirtilmelidir. Bu ilkeye uymayan muhabir veya yazar haber veya yazıyı kendine mal etmiş, intihal yapmış sayılır ve etik ilkelerden sapar (Bülbül, 2001, s. 53).

\section{Fotoğraf ve Görüntü Sorunları}

Medya etiğinin bir gereği olarak fotoğraflarda yanıltmalara başvurulmamalıdır. Fotomontaj gibi yöntemlere yönelinmemelidir. Aksi takdirde hem basın-yayın organı hem de haberci güven kaybeder (Bülbül, 2001, s. 80). 


\section{Kişisel Çıkarlar}

Gazetecilik bir kamu görevidir; onun için özel ve ahlaka aykırı amaçlara ve çıkarlara araç kılınmamalı, kamu yararına zarar verecek şekilde kullanılmamalıdır (Hatemi, 1976, s. 202). Bir çıkar karşılığında haber yapılması açık bir meslek etiği ihlalidir. Bunu önlemek için yayından evvel karar alınması ve haberle ilgili önyargı ve kuşku yaratacak her cinsten hediye ve maddi çıkarın reddedilmesi gerekmektedir (Türkiye Gazetecileri Hak ve Sorumluluk Bildirgesi, 2012, s. 24). Haberciler ise reklam verenlerin, şirketlerin ve iletişim departmanlarının haberlerini etkilemelerine izin vermemeli; iltimas ve para karşılığı haber talep eden mecralardan uzak durmalıdır. UNESCO Basın Ahlakı Projeleri’nde bu konuya değinilmiştir. Projelerde haberlerin tanıtımını etkileyebilecek her türlü bağışın ve rüşvetin reddedilmesi önerilmiş; aksi takdirde ahlaki sorunların doğacağına işaret edilmiştir.

Gerek habercilerin patronlarını koruma ve kollama çabaları gerek kendi menfaatleri için mesleğin sağladığı gücü başka faaliyetlerde kullanmak etik açıdan son derece sakıncalıdır. Örneğin sporcu transferlerine aracılık etmek, sanatçı organizasyonlarında rol almak ya da muhtelif kuruluşlara danışmanlık yapmak, bu kapsamdaki tenkitlerin odağındadır (Yüksel vd. s. 183). Bu konuya pek çok kurum ve dernek önemle eğilmiş; ticari menfaatlere dayalı haber ve yayınlara itibar edilmemesini önermiştir.

\section{Siyasi Bir Haber İncelemesi}

Siyasi haberler, iç ve dış siyasi olayları, durumları konu almaktadır. Türkiye'de siyasi haberlerin önemli bölümü Ankara’dan bildirilmektedir. Çünkü siyasi karar alıcılar, bu şehirde bulunmaktadır. Yani siyasi karar alıcı kurum ve aktörler ile ilgili tüm eylemler, siyasi haberlerin sınırlarındadır. Basın organlarının temsil ettiği sermaye ve ideolojilere bağlı olarak bu tür haberlerde etik değerlerden sapmalar görülebilmektedir. Çalışma kapsamında siyasi bir haber, siyasi bir kurumda geçen, siyasi bir aktörü hedef alan, siyasi nedenlere dayandırılan ve siyasi yankılar uyandıran CHP Genel Başkanı Kemal Kılıçdaroğlu’nun 8 Nisan 2014 tarihinde Meclis’te bir şahsın yumruklu saldırısına uğraması olayı incelenmiştir. Söz konusu saldırıya basının verdiği önem ve saldırı ile ilgili detayları ele alış biçimleri değerlendirilmiştir.

Gazeteler olayları detaylı olarak sunarak radyo, TV ve internet gibi mecraların haberlerini yönetip yönlendirmede rol oynamaktadır. Tahlil edilen gazetelerin sermayedarları gibi siyasi eğilimleri de ayrıdır: Hürriyet, Sabah, Sözcü, Zaman ve Yeni Akit. Olayın meydana geldiği 8 Nisan 2014 tarihinden sonraki üç gün (9-11 Nisan 2014) incelemeye tabi tutulmuştur. Çünkü haberin en çok verildiği; saldırı ile ilgili iddiaların, bulguların en yoğun olduğu dönem bu üç gündür. İncelemede toplam 74 haber kodlamaya dâhil edilmiştir. Bu kapsamda haberlerin yayınlandığı gazete, manşet/ sürmanşet, anahtar sözcükler, yorumlayıcı ve suçlayıcı cümleler inceleme ve karşılaştırma başlıkları olarak seçilmiştir. CHP Genel Başkanı Kemal Kılıçdaroğlu’na saldırı olayının beş gazeteden sunumu ile ilgili bulgular aşağıda yer almaktadır: 
Tablo 1: Haberlerin Yayınlandığı Gazeteler ve Bazı Göstergeler

\begin{tabular}{|l|c|c|c|}
\hline Gazeteler & Haber Sayısı & Manşet Sayısı & Sayfa Sayıs \\
\hline Sözcü & 25 & 3 & 6 \\
\hline Hürriyet & 22 & 2 & 8 \\
\hline Zaman & 11 & 1 & 6 \\
\hline Sabah & 10 & 0 & 6 \\
\hline Yeni Akit & 6 & 0 & 4 \\
\hline Toplam & 74 & 7 & 30 \\
\hline
\end{tabular}

Saldırı haberlerine beş gazete aynı oranda yer vermemiştir, bu durum sayfa sayısından da anlaşılmaktadır. Haber sayısında ilk sırada 25 haber ile Sözcü yer almaktadır. Onun ardından 22 haber ile Hürriyet, 11 haber ile Zaman, 10 haber ile Sabah, 6 haber ile Yeni Akit gelmektedir. Manşet de konuya verilen önemi atfetmektedir. Bu çerçevede saldırı haberi, Sözcü’de 3 manşet, Hürriyet'te 2 manşet, Zaman'da 1 manşetle karşılık bulmuştur. Sabah ve Yeni Akit ise haberi 9-10 Nisan 2014 tarihlerinde ilk sayfada vermiş, manşete taşımamıştır. Söz konusu gazeteler, 11 Nisan 2014'te de haberi ilk sayfada vermemiştir.

Tablo 2: Haberlerle ilgili Görsel Materyaller

\begin{tabular}{|l|c|c|c|c|c|}
\hline Görsel materyaller & Sözcü & Hürriyet & Zaman & Sabah & Yeni Akit \\
\hline Fotoğraf & 32 & 28 & 9 & 12 & 9 \\
\hline Karikatür & 0 & 1 & 0 & 2 & 0 \\
\hline Belge & 2 & 0 & 0 & 0 & 0 \\
\hline Toplam & 34 & 29 & 9 & 14 & 9 \\
\hline
\end{tabular}

Haberlerde kullanılan fotoğraf, belge ve karikatürler olayın hangi çerçeveden görüldügüne işaret eder. Kılıçdaroğlu’na saldırı haberlerinde görsel materyal kullanımında birinci 34 görsel ile Sözcü, ikinci 29 görsel ile Hürriyet olmuştur. Bunları 12 ile görsel Sabah, 9 görsel ile Zaman ve Yeni Akit izlemiştir (Tablo 2). Fotoğraftan en çok yararlananlar 32 fotoğraf ile Sözcü olmuştur. Hürriyet 28, Zaman 9, Sabah 12, Yeni Akit 9 fotoğrafa yer vermiştir. Fotoğraf kullanımı haberi daha görünür kılmakta, okuyanlarda ilgi uyandırmaktadır. İncelemede bu konuya en duyarlı gazetenin Sözcü ve Hürriyet olduğu görülmektedir.

Öte yandan saldırı ile ilgili en çok belge ( 2 adet) Sözcü, en çok karikatür (2 adet) Sabah tarafından verilmiştir. Bu da gazetelerin olaya ne oranda ciddiyetle eğildiğini ortaya koymaktadır. Belgeleme, olaya ehemmiyet verme; içeriği itibariyle olayı basitleştirerek karikatürize etme ise olayı ciddiye almama olarak anlaşılabilir.

Tablo 3: Haberlerin Anahtar Sözcükleri

\begin{tabular}{|l|c|c|c|c|c|c|}
\hline Anahtar Sözcükler & Sözcü & Hürriyet & Zaman & Sabah & Yeni Akit & Toplam \\
\hline Saldırı & 44 & 33 & 23 & 29 & 35 & 164 \\
\hline
\end{tabular}




\begin{tabular}{|l|c|c|c|c|c|c|}
\hline Yumruk & 34 & 14 & 9 & 11 & 18 & 86 \\
\hline Güvenlik & 11 & 19 & 16 & 7 & 0 & 53 \\
\hline Kınama & 8 & 2 & 2 & 10 & 1 & 23 \\
\hline
\end{tabular}

Gazetelerin habere dair değerlendirmeleri anahtar sözcük sayıları ile de yapılabilir. Yumruklu saldırı ile ilgili haberlerde çokça kullanılan ifadelerden yararlanılarak beş gazetenin olayı anlama biçimi ve eğilimi belirlenebilir. Burada haberlerde saldırı, yumruk, güvenlik ve kınama ifadeleri çokça kullanılmıştır. Tablo 3'te görüldüğü üzere, saldırı sözcügüne en çok 44 sözcük ile Sözcü yer vermiştir. Onun ardından 35 sözcük ile Yeni Akit, 33 sözcük ile Hürriyet, 29 sözcük ile Sabah, 23 sözcük ile Zaman gelmiştir. Yumrukta da aynı eğilim görülmüştür. Bu konuda 34 adet ile Sözcü birinci iken, onu 18 sözcük ile Yeni Akit, 14 sözcük ile Hürriyet, 11 sözcük ile Sabah ve 9 sözcük ile Zaman izlemiştir. Güvenlik ifadesine en büyük önemi Hürriyet vermiştir. Bu ifade Hürriyet'te 19, Zaman'da 16, Sözcü'de 11, Sabah'ta 7 defa geçerken, Yeni Akit'te kendine yer bulmamıştır. Kınama ise Sabah'ta 10, Sözcü'de 8, Hürriyet ve Zaman'da 2, Yeni Akit'te 1 kere geçmiştir.

Tablo 4: Haberlerde Geçen Konular

\begin{tabular}{|l|c|c|c|c|c|c|}
\hline $\begin{array}{l}\text { Haberlerde Geçen } \\
\text { Konular }\end{array}$ & Sözcü & Hürriyet & Zaman & Sabah & Yeni Akit & Toplam \\
\hline $\begin{array}{l}\text { Saldırının Meclis'te } \\
\text { olması }\end{array}$ & 8 & 4 & 6 & 3 & 2 & 23 \\
\hline $\begin{array}{l}\text { Kılıçdaroğlu'na } \\
\text { müdahale }\end{array}$ & 4 & 4 & 3 & 5 & 2 & 18 \\
\hline $\begin{array}{l}\text { Saldırı sonrası } \\
\text { arbede }\end{array}$ & 4 & 3 & 2 & 1 & 3 & 13 \\
\hline $\begin{array}{l}\text { Meclis'te güvenlik } \\
\text { zafiyeti }\end{array}$ & 4 & 3 & 2 & 0 & 0 & 9 \\
\hline $\begin{array}{l}\text { Saldırganın kimliği, } \\
\text { sabıkası }\end{array}$ & 3 & 3 & 3 & 4 & 0 & 13 \\
\hline $\begin{array}{l}\text { Saldırganın AK } \\
\text { Parti üyeliği }\end{array}$ & 3 & 4 & 2 & 1 & 1 & 11 \\
\hline $\begin{array}{l}\text { Saldırıya tepki ve } \\
\text { kınamalar }\end{array}$ & 3 & 3 & 2 & 3 & 3 & 14 \\
\hline $\begin{array}{l}\text { Bakanlara } \\
\text { saldırılara } \\
\text { tepkisizlik }\end{array}$ & 0 & 0 & 0 & 1 & 5 & 6 \\
\hline $\begin{array}{l}\text { Saldırganın } \\
\text { Facebook Paylaşımı }\end{array}$ & 4 & 2 & 1 & 0 & 0 & 7 \\
\hline
\end{tabular}

Kemal Kılıçdaroğlu'nu hedef alan saldırıyı gazeteler ayrı yönleriyle ele almıştır. Saldırının yapıldığı yer, saldırıya uğrayanın durumu, saldıran ile ilgili haberler beş 
gazetede aynı ağırlıkta değildir. Örneğin saldırganın Facebook’tan Başbakan Recep Tayyip Erdoğan ile ilgili olumlu paylaşımlarını Sabah ve Yeni Akit görmemiş; Sözcü 4, Hürriyet 2, Zaman 1 haberde ana tema olarak kullanmıştır. Yine saldırganın kimliği, sabıkası ve AK Parti üyeliği en çok Hürriyet tarafından merceğe alınmıştır. Bu anlamda Hürriyet 7, Sözcü 6, Zaman ve Sabah 5, Yeni Akit 1 haber yapmıştır (Tablo 4). Olayın Meclis çatısı altında olması gazetelerce en çok ele alınan konudur. Konuya Sözcü 8, Zaman 6, Hürriyet 4 haberde; Sabah 3, Yeni Akit 2 haberde temas etmiştir. Gazetelerin tamamı; iki yumruk darbesi alan Kemal Kılıçdaroğlu’nun durumuna ve ilk müdahalesine -aynı oranda olmasa da- yer vermiştir. Bu yönde yapılan 18 haberin 5’i Sabah'a, 4'ü Hürriyet ve Sözcü’ye, 3'ü Zaman'a, 2’si Yeni Akit’e aittir. Saldırı sonrası ve saldırganın korumalar tarafından dövülmesi Sözcüde 4, Hürriyet’te 3, Yeni Akit’te 3, Zaman'da 2, Sabah'ta 1 habere girmiştir. Meclis'te güvenlik zafiyeti; Sözcü'de 4 haberde, Hürriyet'te 3 haberde, Zaman'da 2 haberde bulunurken, Sabah ve Yeni Akit'te metinlere girmemiştir. Saldırı olayı sonrasında yapılan sükûnet çağrısı en çok 3 haber ile Zaman'dan ilgi görmüştür. Onun ardından 2 haber ile Sözcü ve Sabah, 1 haber ile Hürriyet gelmiştir.

Tablo 5: Haberlerde Geçen Yorumlayıcı ve Suçlayıcı Cümleler

\begin{tabular}{|c|c|}
\hline Gazeteler & Varsayıma Dayalı ve Suçlayıcı Cümleler \\
\hline Sözcü & $\begin{array}{l}\text { "Tayyip’in ayrıştırıcı söylemi sempatizanlarını dolduruşa getirdi. } \\
\text { Onlardan biri CHP Lideri’ni Meclis'te yumrukladı, demokrasi ağır } \\
\text { yara aldı." } \\
\text { "Ayrıştırıcı, ötekileştirici, kutuplaştırıcı siyaset dilinin ülkeye } \\
\text { verdiği zarar dün açıkça ortaya çıktı." } \\
\text { "Yumruğu yiyen Tayyip olsaydı yumrukçuya 'terörist 'derlerdi, } \\
\text { yedi sülalesi araştırılıdı." } \\
\text { "Demokrasi ağır yara aldı." } \\
\text { "Demokrasiye kara leke olarak geçti”" }\end{array}$ \\
\hline Hürriyet & - \\
\hline Zaman & - \\
\hline Sabah & - \\
\hline Yeni Akit & $\begin{array}{l}\text { "Kemal Kılıçdaroğlu’na yönelik yumruklu saldırı olayı CHP’nin } 30 \\
\text { Mart hezimetini unutturdu." } \\
\text { "CHP’liler yumruklu saldırıya maruz kalan Bakan Taner Yıldızla } \\
\text { alay etmişti.” } \\
\text { "CHP’liler Bozdağ’a yönelik alçaklığa alkış tutmuştu." }\end{array}$ \\
\hline
\end{tabular}

Haber metinlerinde yorumlara, suçlamalara, varsayımlara dayanan cümleleri Hürriyet, Zaman ve Sabah kullanmaktan kaçınmıştır. İktidara yakın olarak değerlendirilen Yeni Akit 3, muhalif olarak değerlendirilen Sözcü 5 haberde yorum, 
suçlama ve varsayımda bulunmuştur. (Tablo 5)

Yeni Akit’te "Kemal Kılıçdaroğlu'na yönelik yumruklu saldırı olayı CHP’nin 30 Mart hezimetini unutturdu” cümlesi ile 30 Mart seçiminin CHP için büyük bir mağlubiyet olduğu savunulmuş, olayın mağlubiyeti örtmeye yönelik mizansen olabileceği ima edilmiştir. "CHP'liler yumruklu saldırıya maruz kalan Bakan Taner Yıldız ile alay etmişti.”; “CHP’liler Bozdă̆’a yönelik alçakliğa alkış tutmuştu.” cümleleri ile de yumruklu saldırılara aynı tepkilerin verilmediği ifade edilmiş, olayın herkese göre aynı görülmediğine temas edilmiştir. Bu cümlelerde açık açı suçlamada bulunulmuştur. Sözcüde "Saldırı demokrasiye kara leke olarak geçti."; "Ayrıştırıcı, ötekileştirici, kutuplaştırıcı siyaset dilinin ülkeye verdiği zarar dün açıkça ortaya çıktı."; "Tayyip'in ayrıştırıcı söylemi sempatizanlarını dolduruşa getirdi. Onlardan biri CHP Liderini Meclis’te yumrukladı, demokrasi ă̆ır yara aldı." cümleleri yanlı bir tavrı ifade etmiştir. Gazetede bir haberde "Yumruğu yiyen Tayyip olsa" ibaresi kullanılmış, akabinde varsayımlarda bulunularak olabilecekler sıralanmıștır. Burada da varsayımlar üretilmesi, ihtimallere gönderme yapılması yanlılı̆̆a ve tarafgirliğe işaret etmiştir.

\section{Sonuç}

Demokratik ülkelerde yasama-yürütme ve yargının ardından dördüncü kuvvet olarak anılan medya kamusal hizmet görmektedir. Sorun veya sorunları görünür kılan, tartıştıran, toplumun bir bölümünü ya da önemli bölümünü belli bir fikirde buluşturabilen medya, bu kuvveti ve kudreti ile hem siyasilerin hem yatırımciların ilgisini çekmektedir.

İletişim teknolojisindeki gelişmeyle birlikte medyanın artan etki gücüne paralel olarak, siyasi yapıların doğrudan veya dolaylı olarak medyayı yanına alma (ya da etkisizleştirme) gayreti de artmaktadır. Aynı şekilde, medya sermayedarları ve yetkilileri de bu ilgiyi şahsi çıkara dönüştürebilmektedir. Bu iktidar mücadelesi, kimi zaman medyaya yönelik sınırlamaların ve sonuçta medyada tek sesliliğin artmasına sebebiyet verebilmektedir. İktidarlar, menfaatlerine uymayan medya gruplarına sansür uygulayabilmekte ya da akreditasyona başvurabilmektedir. Netice itibariyle hem iktidara yakın hem de baskı altındaki medya grupları için mesleki etik ilkeleri çerçevesinde objektif habercilik yapma imkânları güçleşmektedir.

İnşaat, enerji, finans gibi oldukça ayrı sektörlerde yatırımları bulunan medya sermayedarları, rakiplerine karşı korunma ve siyasilerden menfaat elde etme gibi gerekçelerle yayınlara müdahale edebilmektedir. Bu müdahalelerle yayın ve haber kadrosunun iradesine darbe vurulmakta; basın özgürlüğü ve halkın haber alma hakkı engellenmektedir. Bu ortamda medya özgürlüğünden ve etik ilkelerden söz edilememektedir. Medya etiği bakımından haberlerin doğru olup olmadığı, yorum içerip içermediği, suçlamalara dayanıp dayanmadığı, uygun yöntemlerle elde edilip edilmediği hususları en temel tartışma konularıdır. Mesleki etik kurallara ilişkin olarak medya tarihi boyunca tartışılıp geliştirilen yazılı metinler, haber süreçlerinde ve bunlara ilişkin tartışmalarda basın-yayın organlarına rehberlik etmektedir. 
Medyada haber etiğinin teorik temellerinin anlatıldığı çalışmada örnek olay olarak CHP Genel Başkanı Kemal Kılıçdaroğlu'na Meclis'te yapılan yumruklu saldırı olayı tahlil edilmiştir. Bu kapsamda beş gazetenin olayı ele alış şekli incelenmiştir. Tahlillerin sonucunda, saldırı olayını gazetelerin aynı çerçeveden görmedikleri ve olaya siyasi duruşlarına bağlı olarak ayrı anlamlar verdikleri anlaşılmıştır. İktidara yakın duran gazetelerin olayı manşetlerine taşımadı̆̆ı; olaya sayfalarında yeterince yer vermediği, hatta kimi zaman olayı önemsizleştirmeye çalıştıkları görülmüştür.

Tahlillere göre, kimi gazeteler; yorumlara, suçlamalara ve varsayımlara dayanan başlıklar atmıştır. Abartılı ifadeler ve kanıtlara dayanmayan iddialar da haber metinlerinde yer almıştır. Verilerin toplanıp karşılaştırılmasının ardından gazetelerin ağırlıklı olarak siyasi olaylarda yanlı davrandıkları, kendilerini mahkeme gibi gördükleri, etik değerlere riayet etmedikleri anlaşılmıştır.

Medya ve haber etiği ile ilgili tartışmaları asgariye indirmek için, etik değerler ve ilkeler olabildiğince geniş bir görüş birliğiyle ve çok daha açık bir biçimde yeniden ele alınmalıdır. Basın yayın meslek mensupları ve/veya kurumlarının etik ilkelere uymaması durumunda işletilecek yaptırımların caydırıcı ve -daha önemlisiuygulanabilir mahiyette olması sağlanmalıdır. Haberciler mutlaka siyasi ve mali baskılardan bağımsız olmalıdır. Yüzyılların birikimi olan mesleki etik ilkelerinin titizlikle uygulanmasını sağlamak, sağlıklı bir yayıncılık yapmanın en temel koşuludur.

\section{Kaynakça}

Almagor, Raphael Cohen. 2002. İfade, Medya ve Etik. Çev., S. Nihat Şad. Ankara: Phoenix Yayınevi.

Atabek, Nejdet. 2006. "Gazete Haberlerinde Etik Standartların Yükseltilmesinde Okur Temsilcisinin Rolü”. Küresel İletişim Dergisi, 2.

Banar, Seçil. 2013. “Medyada Temel Ayrımlar ve Etiğe İlişkin Değerler”. Medya ve Etik, ed., Ayhan Oğuz Ünlüer, Eskişehir: Anadolu Üniversitesi Yayınları.

BBC’nin Editoryal Değerleri. BBC’nin internet sitesi, www.bbc.co.uk/turkish/ilkeler/ ch1.pdf Erişim: 05.04. 2014.

Belsey Andrew, Chadwick Ruth 2011. Medya ve Gazetecilikte Etik Sorunlar. Çev., Nurçay Türkoğlu. İstanbul: Ayrıntı Yayınları.

Bülbül, Rıdvan. 2001. İletişim ve Etik. 2. Baskı. Ankara: Nobel Yayın Dağıtım.

Çaplı, Bülent. 2002. Medya ve Etik. Ankara: İmge Kitapevi.

Demir, Vedat. 2006. Medya Etiği. İstanbul: Beta Yayınları.

Doğan Yaym Grubu Ortak Değerleri. Doğan Holding'in internet sitesi, www. doganholding.com.tr/_files/pdf/yayin_ilkeleri_yazili_basin. Erişim: 08.04.2014.

Erondu, A. Emmanuel, Alex Sharland, John O. Okpara. 2004. "Corporate Ethics in Nigeria: A Test of Concept of an Ethical Climate”. Journal of Business Ethics, 51/4. 
Girgin, Atilla. 2005. Haber Yazmak. 3. Baskı. İstanbul: Der Yayınları.

Girgin, Atilla. ve Adem Ayten. 2013. “Türkiyede Basın Etiği, Sorunlar ve Etik Uygulamalar”. Medya ve Etik, ed., Ayhan Oğuz Ünlüer, Eskişehir: Anadolu Üniversitesi Yayınları.

Gürkan, Nilgün. 1997. “Türkiyede Siyasal Tikanma ve Medya”. Birikim Dergisi, 104. Hatemi, Hüseyin. 1976. Basın Ahlakı. İstanbul: Çı̆̆ır Yayınları.

Özgen, İhsan Mahmut. 1994. İnsanlık ve Sosyolojik Boyutlarıyla Basın Meslek Ahlakı ve Yasalar. İstanbul: Filiz Kitabevi.

Özgen, Murat. 2002. Gazetecinin Etik Kimliği. İstanbul: İstanbul Üniversitesi İletişim Fakültesi Yayınları.

Özön, Mustafa Nihat. 1971. Osmanlıca Türkçe Sözlük. 1. Baskı. Ankara: Bilgi Yayınevi.

Ramonet, Ignacio. 2000. Medyanın Zorbalı̆̆ı. Çev., Aykut Derman. İstanbul On İletişim.

Şimşek, Sedat. 2009. “Medya-Siyaset-İktidar Üçgeninde Medya Gerçeği”. Selçuk İletişim. 6/1.

Taş, Oğuzhan. 2010. “Medya Etiğinin Tarihsel Temelleri ve Gelişimi”. Televizyon Haberciliğinde Etik. Ed., Bülent Çaplı ve Hakan Tuncel. Ankara: Fersa Yayınevi.

Tepe, Harun. 1992. Etik ve Metaetik. Ankara: Türkiye Felsefe Kurumu.

Türkiye Gazetecileri Hak ve Sorumluluk Bildirgesi. 2012. İstanbul: Türkiye Gazeteciler Cemiyeti Yayınları.

Toruk, İbrahim. 2007. “Türkiye’deki Medyanın Sahiplik Yapısındaki Değişimler”. Bir Sorun Olarak Gazetecilik. Ed., Bilal Arık ve Mustafa Şeker. Konya: Tablet Yayınları.

Ünlüer, Ayhan Oğuz. 2006. "Medyada Etik Söylem ve Medya Etiğini Biçimleyen Temel Belirleyiciler Üzerine Bir Değerlendirme”. Küresel İletişim Dergisi, 2.

Yüksel, Erkan. 2013. "Haber Yazmada Denetim ve Doğrulama”. Haber Yazma Teknikleri, ed., Erkan Yüksel, Eskişehir: Anadolu Üniversitesi Yayınları. 


\title{
News Ethics and An Analysis of a Political News
}

BUĞRA KARDAN

\begin{abstract}
Debates on ethics in media and journalism has a long-standing history, just as the history of media. Due to the opportunities provided by communication technologies, power, influence and functions of the press and media increase and so that play an instrumental role in maximization of the political and/or financial ambitions of political or economic actors. Hence, debates on news ethics continue forever to be a major issue. This study focuses on ethical issues in the news and more specifically political news; elaborates on a news about the violence that a political party leader faced in Turkey, and analyzes how media (newspapers) from different political views reflected the case. As a result of the study, it has been observed that newspapers presented the event largely according to their political positions and worldviews.
\end{abstract}

Keywords: Media, News ethics, Media ethics, Objectivity. 